\title{
'Political fix' saves Kyoto deal from collapse
}

Jim Giles, Bonn

The Kyoto Protocol took a critical, if shaky, step forward this week as the latest round of climate-change talks ended in Bonn, Germany. Almost 180 countries signed up to rules that take the agreement on limiting greenhouse-gas emissions a step closer to coming into force next year.

The talks were marked by a series of concessions by the European Union (EU). The United States' withdrawal from the accord earlier this year, together the failure of the previous set of talks, held in The Hague last November, had raised fears that the process could collapse altogether. The compromises agreed on 23 July, after days of round-theclock negotiations, were accepted by the EU to prevent countries such as Japan and Canada following the United States in rejecting the protocol.

The main EU concession was a climbdown over the use of carbon sinks - projects such as planting new forests to absorb carbon dioxide. The original protocol allowed a range of sink activities to be used as credits to increase the amount of greenhouse gases that countries are entitled to emit. But the Umbrella Group - a coalition of industrialized countries that includes Japan and Canada - had been pushing for the inclusion of further sink projects, such as changing the way in which existing forests are managed.

With delegates desperate for agreement, the Umbrella Group succeeded in winning a better deal than the one the EU had rejected in The Hague, allowing them to gain credit from forest-management projects and other new sinks. TheEU also had to back down over plans to put a cap on the total number of credits that countries can earn from sinks and projects such as investing in emissions-reducing technology in developing countries. And although limits were agreed on the extent of the newly included sinks, Japan and Canada negotiated exemptions from these until 2010. "It's a political fix," says a British member of the EU negotiating team. "That's the price of the deal."

The final hours of the meeting also saw exhausted delegates defer a decision on the penalties for countries that fail to meet their targets, which the EU wants to be legally binding. But the EU did secure one of its aims - the rejection of nuclear power as a means of cutting emissions. Umbrella Group countries had wanted to be able to claim credits by replacing fossil-fuel power stations with nuclear ones. Some had also requested credit for helping developing countries to build nuclear power stations.

Environmental groups are disappointed that the treaty has been watered down. According to the WWF, the current agreement will achieve a $2 \%$ cut in greenhouse-gas emissions by 2010, rather than the $5 \%$

predicted under the original protocol. Sink projects are likely to improve this figure somewhat, although it is unclear by how much.

Nevertheless, the main reaction is one of

relief that the Kyoto process is not dead. "This will send a message to the market," says Jennifer Morgan of the WWF. "It must factor in the cost of carbon."

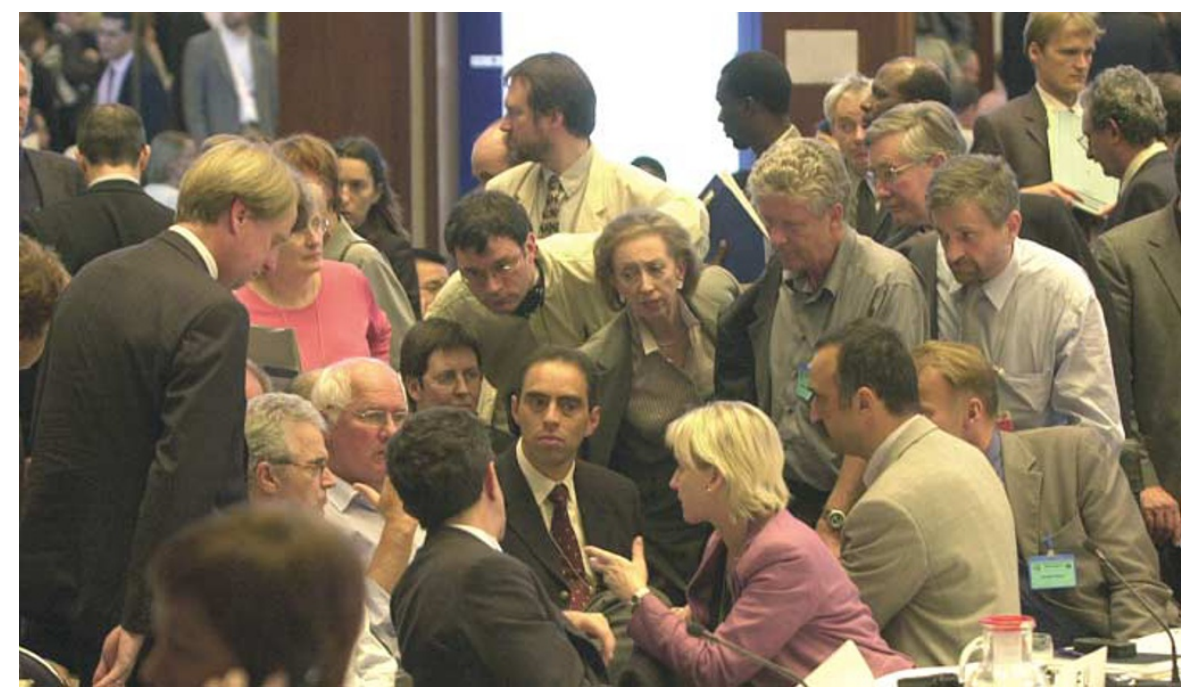

Real deal: delegates in Bonn have settled on a watered-down version of the original agreement.

\section{US rejects bioweapon inspections}

\section{Jonathan Knight, San Francisco}

A plan that would give teeth to the Biological Weapons Convention seems to be doomed. US negotiators will tell this week's talks on the convention in Geneva that they still strongly object to the inclusion of a verification procedure in the treaty.

In all, 140 countries have ratified the convention since it was hammered out almost 30 years ago. But the treaty contains no provision for verification, a loophole that allowed the Soviet Union to operate dozens of germ-warfare facilities in the 1970s and 80s.

Attempts to develop a verification plan began in 1995. It was hoped that the latest draft, released in March, would address the concerns of many participants, including the United States. But as Nature went to press, US representatives were set to announce that they would not sign it in its current form.

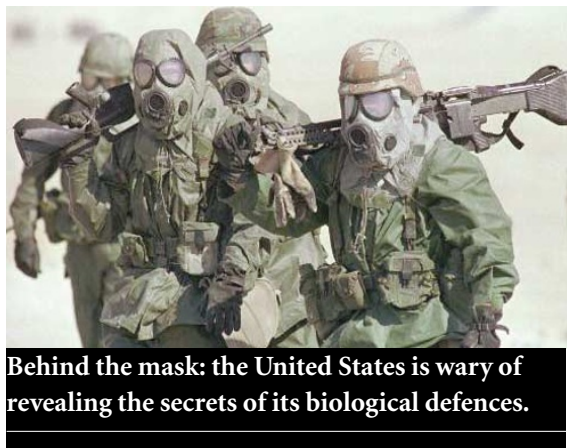

The United States has said in the past that the convention's inspections could threaten trade secrets in its biotechnology industry. A more sensitive issue may be the US biological defence programme, says Amy Rossi of the Federation of American Scientists in Washington. "We don't like the idea that someone could inspect our national labs."

China and Iran both made objections to the draft text in May, mainly over export restrictions. But as the current series of talks got under way on 23 July, both countries said they hoped the protocol would be finalized this year.

They and others may be waiting for the United States to kill the protocol to save themselves the embarrassment, says bioweapons expert Milton Leitenberg of the University of Maryland in College Park. "The Americans and the Chinese are playing this awful game of who's going to get the blame."

The United States is developing a range of measures to counter bioweapons and seems intent on relying on these defences rather than backing the convention. But Matthew Meselson, a molecular geneticist at Harvard University and an adviser to the US government on chemical and biological weapons issues, warns that such an approach could augment suspicions that the United States has something to hide. "There is a huge cost if we just walk away and say we'll look out for ourselves," he says. 